INTIQAD: JURNAL AGAMA DAN PENDIDIKAN ISLAM

ISSN 1979-9950 (print) || ISSN 2598-0033 (online), http://jurnal.umsu.ac.id/index.php/intiqad DOI: $10.30596 /$ intiqad.v11i2.2658

Vol. 11, No. 2 (Desember 2019)

\title{
Pendidikan Karakter Dengan Pendekatan Tasawuf Modern Hamka dan Transformatif Kontemporer
}

\author{
Sofyan Rofi ${ }^{1 *}$, Benny Prasetiya ${ }^{2}$, Bahar Agus Setiawan ${ }^{3}$ \\ ${ }^{* 1}$ Universitas Muhammadiyah Jember, ${ }^{2}$ STAI Muhammadiyah Probolinggo, \\ ${ }^{3}$ Universitas Muhammadiyah Jember \\ *1email: sofyan.rofi@unmuhjember.ac.id \\ 2 email:prasetiyabenny@gmail.com \\ 3email: baharsetiawan@unmuhjember.ac.id
}

\begin{abstract}
This article was written to provide an overview of Character Education with Modern Hamka and Contemporary Transformative Sufism Approaches. The construction of Hamka Sufi thought is very important for the world today, not only for reforming Islamic thought but also for reconstructing modern spirituality. Modern Sufism for Hamka is the application of qanaah, sincerity, and motivation to work Buya Hamka's character education perspective is that the nature of every human being basically leads to always do good and submit to his Khaliq.
\end{abstract}

Artikel Info

Received:

21 Agustus 2019

Revised:

21 Oktober 2019

Accepted:

26 November 2019

Published:

02 Desember 2019

Keywords : character, Sufism, Hamka.

\section{Abstrak}

Artikel ini ditulis untuk memberikan gambaran tentang Pendidikan Karakter Dengan Pendekatan Tasawuf Modern Hamka Dan Transformatif Kontemporer. Konstruksi pemikiran sufi Hamka sangat penting bagi dunia saat ini, tidak hanya untuk mereformasi pemikiran Islam tetapi juga untuk merekonstruksi kerohanian modern. Sufisme modern untuk Hamka adalah penerapan qanaah, ketulusan, dan motivasi untuk bekerja Perspektif pemikiran pendidikan karakter Buya Hamka adalah bahwa fitrah setiap manusia pada dasarnya menuntun untuk senantiasa berbuat kebajikan dan tunduk mengabdi kepada Khaliqnya.

Kata Kunci : karakter, tasawuf, Hamka.

\section{A. Pendahuluan}

Karakter merupakan aspek penting untuk peningkatan kualitas sumber daya masyarakat karena kualitas karakter bangsa menentukan kemajuan suatu bangsa. Karakter adalah gambaran tingkah laku yang menonjolkan nilai benar-salah, baik buruk secara implisit 
INTIQAD: JURNAL AGAMA DAN PENDIDIKAN ISLAM

ISSN 1979-9950 (print) || ISSN 2598-0033 (online), http://jurnal.umsu.ac.id/index.php/intiqad

DOI: $10.30596 /$ intiqad.v11i2.2658

Vol. 11, No. 2 (Desember 2019)

maupun eksplisit. ${ }^{1}$ Untuk itu karakter yang berkualitas perlu dibentuk dan dibina sejak usia dini. Pendidikan karakter dinilai berhasil apabila anak telah menunjukkan habit atau kebiasaan berperilaku baik dan dapat memaknai serta menghargai nilai karakter tersebut. Untuk itu pembentukan karakter anak harus berkaitan dengan aspek kognitif dan dikuatkan dengan aspek afektif. Hal ini tentunya melibatkan berbagai pihak, baik orangtua, guru maupun lingkungan masyarakat.

Pendidikan Agama Islam (PAI) adalah salah satu pilar terpenting pendidikan karakter. Pendidikan karakter akan membangun dengan baik, jika dimulai dari menumbuhkan rasa keagamaan siswa, oleh karena itu, pelajaran PAI menjadi salah satu pelajaran pendukung pendidikan karakter. Melalui pengajaran dan pembelajaran PAI, para siswa diajarkan kepercayaan akan Tuhan sebagai dasar agama mereka, diajarkan al quran dan hadits sebagai cara hidup mereka, diajarkan fiqih sebagai tanda hukum dalam melakukan pengajaran Islam,

\footnotetext{
1 Alwisol, Psikologi Kepribadian, (Malang : UMM, 2016), h. 67.
}

mengajarkan sejarah Islam sebagai contoh kehidupan yang baik, dan mengajarkan etika sebagai cara karakter manusia. $^{2}$

Tafsir al-Azhar adalah salah satu karya agung ulama terkenal Indonesia iaitu Hamka. Tafsir ini tergolong antara tafsir-tafsir besar jika diteliti dari sudut perbahasannya. Keistimewaan Tafsir alAzhar, selain membincangkan akhlak dan pembaharuan Islam, ia juga menekankan secara khusus sudut tasawuf, etika, dan permasalahan terkini yang berlaku di Indonesia. Hasil daripada corak pemikiran, kajian dan penulisan terhadap Tafsir al-Azhar, Hamka sekali lagi menghasilkan sebuah buku yang bertajuk Tasauf Modern yang membahaskan dasar- dasar sufisme baru di Indonesia khususnya, dan Singapura umumnya. Buku tersebut menampilkan sebuah pemikiran yang memberi penekanan dan penghayatan dari sudut esoteris atau bāṭiniyyah yang perlu diaplikasikan di dalam diri masyarakat. ${ }^{3}$

Konstruksi pemikiran sufi

2 N. Ainiah,'Pembentukan Karakter Melalui Pendidikan Agama Islam”. Jurnal AlUlum (2003).

3 Abdul Rouf \& Mohd Yakub Zulkifli Mohd Yusoff, "Tafsir al-Azhar dan tasawuf menurut Hamka”. Jurnal Usuluddin (2013). 
Hamka sangat penting bagi dunia saat ini, tidak hanya untuk mereformasi pemikiran Islam tetapi juga untuk merekonstruksi kerohanian modern. Masyarakat modern saat ini terjebak oleh model dan pola pemikiran rasional, membuang dimensi batin atau spiritual, sehingga menghasilkan gaya hidup materialistis dan hedonistik. Akibatnya, muncul krisis nilai kemanusiaan yang ditandai oleh krisis spiritualitas. Pemikiran sufistik Hamka sebagai bentuk rekonstruksi spiritual manusia relevan untuk dipelajari secara mendalam. Untuk membuktikan bahwa spiritualitas merupakan potensi manusia yang tidak mungkin lenyap dalam situasi apa pun, walaupun manusia telah mencapai puncak rasionalitas. Pemikiran sufistik Hamka aktif, dinamis dan progresif, menekankan perlunya keterlibatan seseorang dalam masyarakat lebih aktif daripada dalam sufisme lama. Terlebih lagi, sufisme harus menjadi agen perubahan sosial dari semua jenis dekadensi kehidupan. Bagi Hamka, kerohanian adalah gagasan tanpa batas yang melekat dalam totalitas kemanusiaan. Menyangkal itu berarti meniadakan kedirian manusia. Karena itu, sufisme adalah cara terbaik untuk menghadirkan yang transenden, karena sufisme menjadi kebutuhan manusia pada masa duka. ${ }^{4}$

Tulisan ini bertujuan untuk mengetahui pemikiran Abdul Malik Karim tentang Pendidikan karakter dengan pendekatan tasawuf. Sufisme modern untuk Hamka adalah penerapan qanaah, ketulusan, dan motivasi untuk bekerja. Selain itu, seorang sufi di era modern juga dituntut untuk bekerja dengan rajin dan memiliki niat kepada Allah SWT. Hamka memberikan panduan tentang etika atau tindakan untuk mistikus berdasarkan profesi masing-masing. Ada sejumlah etika di pemerintahan, bisnis dan ekonomi, serta bidang kedokteran. Hamka menulis etika untuk guru, siswa, dokter, pengacara, dan penulis. Jika seorang Muslim dengan beberapa profesi ini mampu menerapkan nilai-nilai Islam, maka, ia dapat disebut sebagai seorang sufi di era modern. Sufisme tidak hanya ditafsirkan sebagai kesendirian asketis, menjauh dari dunia normal, tetapi juga dapat

4 Sutoyo, "Tasawuf Hamka dan Rekonstruksi Spiritual Manusia Modern". Islamica: Jurnal Studi Keislaman (2015). 
ISSN 1979-9950 (print) || ISSN 2598-0033 (online), http://jurnal.umsu.ac.id/index.php/intiqad

DOI: $10.30596 /$ intiqad.v11i2.2658

Vol. 11, No. 2 (Desember 2019)

ditafsirkan untuk bekerja secara aktif. ${ }^{5}$

Dari paparan diatas penulis ingin menggali pemikiran Hamka terkait Pendidikan karakter, sehingga penulis menetapkan judul "PendidikanKarakter dengan Pendekatan Tasawuf Modern Hamka dan Tasawuf Transformatif Kontemporer".

\section{B. Pembahasan}

\section{Pendidikan Karakter Dengan Pendekatan Tasawuf Modern Hamka Dan Tasawuf Transformatif Kontemporer}

Haji Abdul Malik Karim Amrullah yang kerap dipanggil Hamka merupakan seorang intelektual, ulama tafsir, sastrawan, sejarawan dan juga politikus yang sangat terkenal di Indonesia mulai dari masanya hingga sekarang ini. Selain itu, Hamka juga bisa dibilang seorang pembaharu dalam kajian keislaman di Indonesia. Salah satu pembaharuan terpentingnya adalah pengembangankajian tafsir al-Quran dalam studi tafsir dan kajian tasawuf modern dalam kajian tasawuf. Meskipun

5 N. M. Ulfah, \& D. Istiyani, "Etika Dalam Kehidupan Modern: Studi Pemikiran Sufistik Hamka", Esoterik: Jurnal Akhlak dan Tasawuf (2016). demikian yang harus diakui adalah kenyataan bahwa di Indonesia Hamka bukan satu-satunya ulama tafsir dan tasawuf, namun usaha Hamka dalam dua hal ini memiliki bekas yang nyata bagi civitas akademika kalangan Islamic studies.

Hamka dilahirkan di sungai Batang Maninjau (Sumatara Barat) pada 17 Februari 1908 M (14 Muharram 1326 H). Ibunya bernama Syafieciyah dan ayahnya bernama $H$. Abdul karim Amrullah atau yang kerap disapa Haji Rosul, seorang ulama terkenal pembawa paham-paham pembaharuan Islam di Minangkabau. ${ }^{6}$

Ayah Hamka merupakan salah satu tokoh di antara 15 tokoh yang ikut mendirikan Sekolah Persatuan Guru Agama Islam (PGAI) yang diketuai oleh Syekh H. Abdoellah Ahmad, di Minangkabau pada tahun1918 M. Sekolah ini mendapatkan persetujuan resmi dari Kolonial Belanda pada tanggal 5 Agustus 1919 M. $^{7}$

Tasawuf merupakan bagian integral ajaran Islam yang lebih

6 Hamka, Falsafah Hidup (Jakarta: Republika, 2015), h. 98.

${ }^{7}$ Hamka, Ghirah dan Tantangan Hidup Umat Islam, (Jakarta: Bulan Bintang, 1957). 
ISSN 1979-9950 (print) || ISSN 2598-0033 (online), http://jurnal.umsu.ac.id/index.php/intiqad

DOI: $10.30596 /$ intiqad.v11i2.2658

Vol. 11, No. 2 (Desember 2019)

mengedepankan aspek "irasionalitas" (baca: intuisi) daripada aspek rasionalitas (baca: akal). Tasawuf menyokong aspek batin dan sebagai aktualisasi atas ketidakpuasan pelakunya terhadap bentuk pemahaman keagamaan intelektualistik (teolog dan filsuf) serta pemahaman keagamaan formalistiklegalistik (fuqahâ') ${ }^{8}$

Secara umum, tasawuf dipahami sebagai sikap mental yang selalu memelihara kesucian diri, beribadah, hidup sederhana, rela berkorban untuk kebaikan dan selalu bersikap bijaksana. Sikap jiwa yang demikian itu pada hakikatnya adalah akhlak yang mulia.

Tasawuf juga dipahami sebagai praktik spiritual dalam tradisi Islam. Tasawuf memandang rûh sebagai puncak dari segala realitas. Sementara jasad tidak lebih sebagai "kendaraan" saja. Maka, jalan spiritualitas lebih banyak menekankan pada aspek rohani, bersifatpersonal dan berangkat dari pengalaman yang juga bersifat personal. Berbeda dari "agama" yang bersifat umum (dalam Islam dikenal dengan istilah sharî‘ah), jalan tasawuf kemudian

8 Amin Abdullah, Studi Agama: Normativitas atau Historisitas (Yogyakarta: Pustaka Pelajar, 1966), h. 156. dikenal dengan istilah tarekat (dekat dengan istilah tirakat dalam bahasa Jawa). Dalam jalan ini setiap pendaki (sâlik) akan melewati level dan kondisi (maqâmât dan ahwâl) di bawah bimbingan guru spiritual (dalam dunia tasawuf dikenal dengan istilah murshid). Tasawuf, menurut sufi besar Abû Bakr al-Kattâmî （w. 322 H), adalah pembersihan hati dan penyaksian terhadap realitas hakiki, secara harfiah dimaknai "kejernihan" dan "kesaksian". Atau seperti yang dinyatakan oleh seorang tokoh sufi terkenal Ma'rûf alKarkhî "melepaskan diri dari segala kepalsuan". 9 Dengan demikian, penulis menggarisbawahi bahwa segala rupa praktik yang secara lahiriah menampakkan atau mengklaim diri mengikuti tasawuf tentu tetap patut diragukan terlebih dahulu serta diperlukan pencermatan yang lebih mendalam sebelum terbukti bahwa ia adalah ajaran tasawuf yang benar dan sesuai dengan koridor Islam.

Sementara itu menurut Hamka, tasawuf ibarat jiwa yang menghidupkan tubuh dan merupakan jantung dari keislaman.

${ }^{9}$ Said Aqil Siradj, Silat Allâh bi al-Kawn: fî al-Tasawwuf al-Falsafî (Makkah: Jâmi'ah Umm al-Qurâ, 1994), h. 16. 
Akan tetapi Hamka sendiri mengakui adanya berbagai gejala dalam tasawuf yang tidak dibenarkan oleh Islam. Hal ini karena dalam masyarakat modern saat ini berkembang apa disebut dengan tasawuf semu.

Sebagai tokoh modern, Hamka masih menunjukkan minat intelektualnya pada tasawuf, meskipun tidak sedikit tokoh modernis yang cenderung bersikap antitasawuf. ${ }^{10}$ Dasar pemikiran Hamka adalah bahwa di dalam tasawuf masih terdapat nilai-nilai autentik semangat ajaran Islam, khususnya tauhid. Hamka juga memberi ilustrasi tasawuf dalam setiap kehidupan manusia yang menjadi tempat "berpulang" bagi orang-orang yang telah mengalami kepayahan perjalanan dan menjadi tempat "berlari" bagi orang yang telah terdesak. Tasawuf menjadi penguat bagi pribadi orang yang lemah dan menjadi tempat berpijak bagi orang yang kehilangan tempat berpijak.

Namun, menurut Hamka, tidak semua agama relevan untuk ditawarkan pada masyarakat modern. Hal ini disebabkan karena manusia modern sangat mengagungkan hasil pengembaraan

\footnotetext{
${ }^{10}$ Nurcholis Madjid, Tradisi Islam: Peran dan Fungsinya dalam Pembangunan di Indonesia (Jakarta:Paramadina, 1997), h.123
}

intelektual sehingga tidak akan mudah bagi mereka menerima begitu saja suatu sistem kepercayaan. Hanya agama yang tidak menafikan peran rasiolah yang akan bertahan di samping kemampuannya memenuhi kebutuhan spiritualitas yang tidak diberikan oleh ilmu pengetahuan dan teknologi. Di samping itu, watak masyarakat modern yang tanpa batas mengharuskan sebuah sistem ideologi termasuk agamayang dapat bertahan hanyalah yang dapat menghargai berbagai sistem ideologi lain yang berbeda. Inilah barangkali model keberagamaan masa akan datang yang menghadirkan sisi spiritualitas lebih dalam. Spiritualitas seperti inilah yang sejatinya memberikan bingkai secara ideologis bagi kejatidirian manusia dari serangan kehampaan dan keterasingan yang ditimbulkan oleh nilai modernitas.

Hamka juga menjelaskan bahwa tasawuf memiliki sisi positif dan negatif. ${ }^{11}$ Tasawuf menjadi negatif apabila dilaksanakan tidak sesuai dengan tuntunan al-Qur'ân dan al-Sunnah, seperti mengharamkan diri sendiri terhadap hal-hal yang dihalalkan Allah

11 Damami, Tasawuf Positif, Pandangan Hidup Muslim (Jakarta: Bulan Bintang, 1992), h, 177. 
dan berpangkal pada pandangan yang mengharuskan benci terhadap dunia. Sisi positif tasawuf adalah apabila ia dilaksanakan sesuai dengan rumusan alQur'ân dan al-Sunnah, yang berdimensi pada keterkaitan antara ibadah atau hablumminAllâh (ibadah murni) dengan ibadah yang hablumminannas (ibadah sosial nyata). Oleh karena itu, orang yang hendakmempelajari tasawuf harus mengambil ilmu ini dari sumbernya yang dipercaya serta berada di bawah bimbingan seorang mushrif (guru).

Dalam tasawuf modern yang ditawarkan oleh Hamka, seorang sufi harus menempatkan Tuan dalam skala "tauhid". Tauhid dini artinya : Tuhan yang Esa itu ada pada posisi transenden (berada di luar dan di atas terpisah dari makhluk) tetapi sekaligus terasa dekat dalam hati (qalb). Pengertian ini merupakan gabungan antara konsep keakidahan (ilmu kalam) dan konsep "ihsan" menurut Rasulullah SAW. Dengan demikian Tuhan tidak ditempatkan "terlalu jauh" tetapi juga tidak "terlalu dekat". Akidah ini disebut juga dengan akidah sufisme (meminjam istilah Prof. Dr. Simuh).

Ajaran Tauhid sangat ditekankan oleh Hamka, karena bagi dia selama abad ke tiga belas, empat belas dan lima belas, ketika perkembangan Islam ke Indonesia, maka ajaran Islam itu sendiri di seluruh negeri-negeri Islam sedang dipengaruhi oleh ajaran tasawuf yang telah banyak menyeleweng dari pangkalnya. Baik ketika kita pergi ke Mesir, Asia Tengah, Islam diliputi oleh tasawuf yang terpengaruh oleh berbagai macam ajaran yang bukan aslinya. Setelah abad ke tujuhbelas, banyak orang Hadramaut datang ke Indonesia yang bermadzab "Syafi'i'. Mereka pun membawa pemujaan kubur dan keramat yang dinamakan "haul" setiap tahun di samping memperteguh pangaruh madzab Syafi'i tersebut. Tasawuf di Indonesia banyak dipengaruhi dari Persia (Iran) dan India. $^{12}$

Hamka menekankan bertasawuf lewat taat peribadatan (ibadah) yang dituntunkan agama dan merenungkan hikmah (semangat Islam yang tersembunyi) di balik seluruh bentuk dan macam peribadatan itu. Kehidupan tasawuf seseorang baru dapat dikatakan berhasil jika pada diri seseorang tersebut tampak etos sosial yang tinggi, kepekaan sosial yang tinggi (karamah dalam arti

12 Hamka, Lembaga Hidup, (Jakarta: Pustaka Panjimas, 2001), h. 226 
INTIQAD: JURNAL AGAMA DAN PENDIDIKAN ISLAM

ISSN 1979-9950 (print) || ISSN 2598-0033 (online), http://jurnal.umsu.ac.id/index.php/intiqad

DOI: 10.30596/intiqad.v11i2.2658

Vol. 11, No. 2 (Desember 2019)

sosio-relgius) Sama dengan juga

kehormatan yang disebabkan kiprah dan jasa sosial yang dimotivasi oleh dorongan kesalehan dalam menjalankan syariah agama). Inilah yang disebut dengan refleksi hikmah. Tasawuf juga bukanlah menjadi suatu tujuan. Tasawuf merupakan buah hasil dari pelaksanaan peribadahan yang benar dan ikhlas. ${ }^{13}$

Salah satu dari jalan tasawuf adalah kefakiran (poverty). Arti kefakiran (memiliki sesedikit mungkin barang-barang duniawi dipandang secara meyakinkan sebagai yang sangat mungkin mencapai keselamatan) dalam arti sesungguhnya itu bukan berarti semata-mata kekurangan dalam hal kekayaan, tetapi bahkan tidak memiliki keinginan untuk memperoleh kekayaan ini dapat diandaikan kosongnya hati (dari keinginan terhadap perolehan kekayaan) sebagaimana kosongnya tangan (karena tidak memegang apaapa). Jadi konsep kefakiran itu menampak dengan tidak memiliki apaapa, hati pun juga tidak menampak dengan:tidak memiliki apaapa. Sungguh pun begitu, konsep ini mengandung arti yang sesungguhnya seperti itu. Sebab,

${ }^{13}$ Damami, Tasawuf Positif..., h. 218. bisa saja ada seorang sufi yang punya harta benda banyak, namun dia merasa tidak memiliki harta benda itu, hatinya dapat "berjarak" dengan semua harta kekayaan itu.

Menurut rincian Reynold A Nicholson, terdapat beberapa jalan tasawuf di antaranya: kefakiran (poverty), penahanan diri (mortification), penyerahan dirikepada Tuhan (trust in good) dan dzikir (recollection). Penahanan diri berarti memisahkan nafsu dari hal-hal yang telah di lakukannya, dengan demikian seseorang terdorong untuk melawan hawa nafsunya. Penyerahan diri kepada Tuhan yaitu adanya pengingkaran terhadap setiap inisiatif dan kemauan diri. Sedangkan zikir berarti menyebut (mentioning), mengingat-ingat (remembering). Caranya dengan mengingat Allah secara berulang-ulang

\section{Pendidikan Karakter Dengan Pendekatan Tasawuf Modern Hamka}

Pandangan Hamka tentang pendidikan adalah bahwa pendidikan sebagai sarana yang dapat menunjang dan menimbulkan serta menjadi dasar bagi kemajuan dan kejayaan hidup 
manusia dalam berbagai keilmuan. ${ }^{14}$ Melalui pendidikan, eksistenisi fitrah manusia dapat dikembangkan sehingga tercapai tujuan karakter.

Menurut Hamka, fitrah setiap manusia pada dasarnya menuntun untuk senantiasa berbuat kebajikan dan tunduk mengabdi kepada Khaliqnya. Jika ada manusia yang tidak berbuat kebajikan, maka sesungguhnya ia telah menyimpang dari fitrahnya tersebut. Hamka menambahkan, pada diri manusia terdapat tiga unsur utama yang menopang tugasnya sebagai khalifah fi al-ardh maupun 'abd Allah. Ketiga unsur tersebut antara lain akal, hati, dan pancaindra.

Dalam membentuk kepribadian anak, tidak terlepas dari pendidikan orang tuanya. Salahlah pendidikan orang tua yang ingin membuat anaknya seperti dia. Orang tuanya telah membentuk anak-anaknya menurut pembentukan pada masanya terdahulu. Orang tua seharusnya membentuk anaknya mengikuti masa anaknya. ${ }^{15}$ Oleh karena itu, kepandaian dan pendidikan orang tua

${ }^{14}$ Irfan Hamka, Ayah, (Jakarta: Republik Penertbit, 2016), h. 290

15 Ibid, h. 264 dalam mendidik anaknya akan sangat membantu pekerjaan guru.

Pembentukan karakter yang sederhana dapat diperolah dari akal orang yang bijaksana, maka hubungannya dengan pendidikan sangat berpengaruh. Maksud dari pendidikan ialah membentuk anak supaya menjadi anggota masyarakat yang berguna dalam pergaulan hidup. Halini yang dimaksudkan Hamka dari pendidikan karakter ialahmembiasakan berkata terus terang (jujur). Berani karena benar, sabar atas rintangan dan bantahan, tahan kena kritik, dan kuat serta teguh. Perlu adanya pengorbanan yang ditempuh walaupun tidak sedikit akan melewati berbagai rintangan. ${ }^{16}$

Dengan demikian, pendidikan bukan saja sebagai proses pengembangan intelektual dan kepribadian anak, akan tetapi juga proses sosialisasi anak dengan lingkungan dimana ia berada. Dalam membentuk kepribadian anak, orang tua memiliki peran penting dalam menanamkan dasardasar agama, sebab dengan iman yang kuat, maka anak akan mempunyai pegangan hidup yang benar. Sama halnya dengan guru yang memberikan

${ }^{16}$ Ibid, 372 
INTIQAD: JURNAL AGAMA DAN PENDIDIKAN ISLAM

ISSN 1979-9950 (print) || ISSN 2598-0033 (online), http://jurnal.umsu.ac.id/index.php/intiqad

DOI: 10.30596/intiqad.v11i2.2658

Vol. 11, No. 2 (Desember 2019)

keteladanan di sekolah dalam menanamkan nilai-nilai budi pekerti luhur serta dukungan masyarakat sebagai kontrol sosial.

Lebih jelasnya perspektif pemikiran pendidikan karakter Buya Hamka dalam berbagai aspek pendidikan, berikut ini penulis sajikan dalam bentuk tabel untuk mempermudah memahami perspektif pemikiran pendidikan karakter tersebut ditunjukkan dalam table dibawah ini:

\begin{tabular}{|c|c|c|}
\hline & & $\begin{array}{l}\text { perkembangan } \\
\text { jasmaniah dan } \\
\text { mental spiritual } \\
\text { siswa }\end{array}$ \\
\hline 4 & $\begin{array}{l}\text { Peserta } \\
\text { Didik }\end{array}$ & $\begin{array}{lll}\text { - } & \text { Bersikap kritis } \\
\text { kepada guru } & \text { (tidak } \\
\text { taqlid buta) } & \\
\text { - } & \begin{array}{l}\text { Rindu dan cinta } \\
\text { kepada ilmu }\end{array} \\
\end{array}$ \\
\hline 5 & $\begin{array}{l}\text { Pendidikan } \\
\text { Karakter }\end{array}$ & $\begin{array}{llr}\text { - } & \begin{array}{l}\text { Fitrah } \\
\text { manusia }\end{array} & \text { setiap } \\
\text { dasarnya } & \text { berbuat } \\
\text { kebajikan } & \text { dan } \\
\text { tunduk } & \text { kepada } \\
\text { Khaliqnya. } & \\
\text { - } & \begin{array}{l}\text { Pengaruh } \\
\text { pendidikan orang }\end{array} \\
& \text { tua dan agama }\end{array}$ \\
\hline
\end{tabular}

Tabel: Pendidikan Karakter Pemikiran Buya Hamka

\begin{tabular}{|c|c|c|}
\hline No & Aspek & Buya Hamka \\
\hline 1 & Pendidikan & 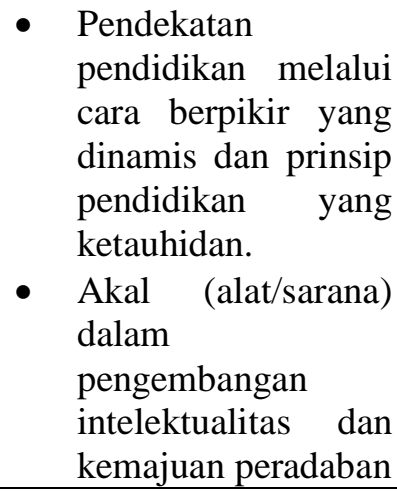 \\
\hline 2 & $\begin{array}{l}\text { Tujuan } \\
\text { Pendidikan }\end{array}$ & 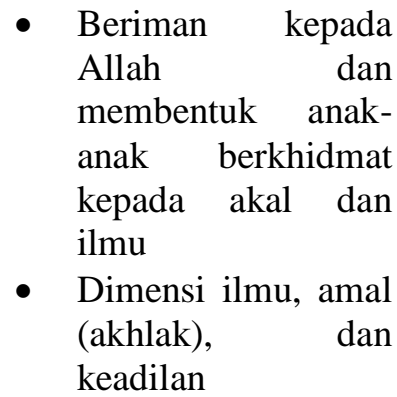 \\
\hline 3 & Pendidik & $\begin{array}{ll}\text { - } & \text { Menjadi teladan } \\
\text { bagi siswanya } \\
\text { - } & \text { Menyesuaikan } \\
\end{array}$ \\
\hline
\end{tabular}

\section{Nilai-Nilai Pendidikan Karakter} Pemikiran Buya Hamka

Adapun perspektif pemikiran Buya Hamka mengandung nilai-nilai pendidikan karakter sebagai berikut :

Religius menurut Buya Hamka Individu yang relegius ialah individu yang melaksanakan ibadah dengan taat, dan segala perkataan dan perbuatan yang dilakukanya sesuai dengan ajaran agama yang dianutnya. Kutipan cerita yang menggambarkan tentang nilai pendidikan karakter relegius yaitu "sebab itu marilah kita ajar diri tunduk kepada syariat dan teguh setia mengerjakan ibadah. Sebab ada titah seruan ibadah yang tidak bermaksud untuk kesucian kita dan membentuk 
jalan hidup kita. Hidup begitulah yang diajarkan oleh Rasul, utusan Tuhan, Sejak dari Adam sampai kepada penutupnya segala Rasul, yaitu Muhammad Saw. Tunduknya segala jiwa dan Zat Yang Maha Besar, yang menguasai segenap benda ini. ${ }^{17}$

Jujur menurut Buya Hamka jujur ialah sesuatu yang di sesuaikan apa yang di ucpakan dengan lisan maupun dihati ataupun perbuatan yang telah dilakukannya dengan kenyataan yang jelas. Kutipan cerita yang menggambarkan tentang nilai pendidikan karakter jujur adalah yaitu “ sesuatu yang dicupakan dengan hati ia akan mudah masuk ke hati". ${ }^{18}$

Seorang yang patut disebut mulia atau budiman, ialah bersikap terus terang, ikhlas jujur pada perkataan dan perbuatannya. Tidak mengambil muka, tidak pula hanya suka dipuji dan tidak tabah ketika dicela. Dia mengerjakan perbuatan baikbukan karena yang lain, tapi semata-mata karena kebaikan itu adalah kebaikan. Tidak pula melupakan jasa orang lain terhadap dirinya, pada menenggang rasa. ${ }^{19}$

\footnotetext{
${ }^{17}$ Ibid, h. 376.

${ }^{18}$ Sutoyo, Tasawuf Hamka...., h. 203

${ }^{19}$ Irfan Hamka, Ayah...., h. 207
}

Bersahabat/Kumunikatif menurut Buya Hamka Bersahabat ialah menjalin bubungan dengan orang lain maka individu akan lebih mudah untuk menemukan jati dirinya sendiri. Bersahabat merupkan salah satu bentuk tolong menolong yang dianjurkan dalam Islam. Bersahabat sangatlah penting untuk mencurahkan hati kita kepada sahabat dan dapat meringankan beban yang ada dalam diri. Kutipan cerita yang menggambarkan nilai pendidikan karakter bersahabat adalah: "Persahabatan adalah satu ilmu tersendiri. Ilmu itu terbagi dua garis besar. Pertama, kesanggupan kita menyelidiki dengan budi yang halus, adakah orang yang akan dijadikan sahabat itu lengkap syarat-syarat tadi atau tidak. Kedua, kesanggupan mencukupkan syara-syarat itu pada diri kita sendiri, untuk kita bayarkan pula kepada sahabat itu, sehingga budi terbalas, dunia bertebus". ${ }^{20}$

Mandiri menurut Buya Hamka kemandirian ialah sikap yang memungkinkan seseorang untuk bertindak bebas melakukan sesuatu atas dorongan sendiri dan kemampuan mengatur sendiri, sesuai dengan hak dan

${ }^{20}$ Ibid, h. 392. 
ISSN 1979-9950 (print) || ISSN 2598-0033 (online), http://jurnal.umsu.ac.id/index.php/intiqad

DOI: 10.30596/intiqad.v11i2.2658

Vol. 11, No. 2 (Desember 2019)

kewajibannya sehingga dapat menyelesaikan sendiri-sendiri masalah yang dihadapi tanpa meminta bantuan dari orang lain dan dapat bertanggung jawab terhadap segalan keputusan yang telah diambil. Kutipan cerita yang menggambarkan tentang nilai pendidikan karakter mandiri yaitu "Percaya kepada diri sendiri adalah tiang budi pekerti yang utama. Yang sanggup memikul hanya orang yang kemanusian tinggi. Percaya diri sendiri menimbulkan usaha sendiri dengan tidak mengharapkan orang lain. Percaya kepada diri sendiri timbul dari jiwa merdeka". ${ }^{21}$

Kerja Keras menurut Buya Hamka kerja keras ialah suatu upaya yang terus dilakukan dengan semangat, tidak pernah menyerah, dalam melakukan suatu tugas sebelum tugas tersebut tercapai dan selalu berdoa agar apa yang kita inginkan diridhoi oleh Allah Swt . Kutipan cerita yang menggambarkan tentang nilai pendidikan karakter kerja keras yaitu "Cita-citalah yang membedakan sebagian manusia dari yang sebagiannya. Kita berusaha mencapai cita-cita jadi orang mulia, orang berpangkat pemimpin, pengarang dan orang alim. Tegasnya menjadi seseorang yang terhormat. Kita bercitacita dan berusaha agar cita-cta tercapai sebelum kita wafat."

Tanggung Jawab menurut Buya Hamka tanggung jawab ialah kesadaran manusia akan tindakan yang dilakukanya baik yang disengaja maupun tidak disengaja. Manusia yang bertanggung jawab adalah mereka yang melakukan tugas dengan penuh sepenuh hati, berusaha keras untuk mencapai sesuatu tujuan yang diinginkan dan yakin terhadap pilihan dan keputusan yang diambil. Kutipan cerita yang menggambarkan tentang nilai pendidikan karakter bertanggung jawab yaitu "Engkau bertanggung jawab di hadapan Allah, engkau akan ditanyai kebaikanmu akan dibalas, kejahatanmu demikian pula. Apa saja yang enkau kerjakan lebih dahulu dan mana pula yang engkau letakkan terkemudian."22

Sederhana menurut Buya Hamka sederhana ialah orang yang tidak berlebih-lebihan terhadap sesuatu, tidak terlalu condong, dan selalu merasa cukup apa yang ia hadapi. Ada pun Hamka memiliki kepribadian yang sederhana yang selalu merasa bersyukur

${ }^{22}$ Irfan Hamka, Ayah...., h. 58 
apa yang ia miliki, kutipan cerita yang menggambarkan nilai nilai pendidikan karakter sebagai berikut :Orang yang sederhana, meskipun terhada perkara yang dibolehkan, dia sederhana juga. Ingat sajalah ketika Rasulullah Saw. hidup, diperintahkan kepada umat Islam supaya turut mengerjakan sholat malam "Qiyamul Lail" (Tahajjud). Tetapi kemudian, tetapi karena ada yang akan mencari rezeki, berniaga dan yang akan pergi ke medan perang, perintah itu diringankan daripada yang semula, hanya diberatkan kepada Nabi Saw saja. $^{23}$ " seketika miskin, orang bercitacita hendak kaya, karena bila harta telah cukup bahagia akan tercapai, sebab dapat membantu sesame hambah Allah. Tetapi setelah dia kaya dia menjadi sombong, harta hendaknya disimpannya, dan dia menjadi kikir". ${ }^{24}$

Demokratis menurut Buya Hamka demokrasi ialah sistem tananan suatu negara yang memberikan kebebasan atas hak-hak rakyatnya dengan adil, dan memberikan kebebasan rakyat untuk berpendapat serta menerima, dan menjalankan pendapat rakyatnya. Kutipan cerita yang menggambarkan

\footnotetext{
${ }^{23}$ Sutoyo, Tasawuf Hamka...., h. 69

${ }^{24}$ Ibid, h. 21
}

karakter demokratis yaitu "Budi pekerti yang pertama itu jika dinisbahkan kepada manusia adalah menjadi kewajiban dan menjadi hak. Dia menjadi kewajiban, karena undang-undang budi pekerti menyuruhnya. Dia menjadi hak, sebab undang-undang kesopanan memberi kebebasan kepada manusia untuk mengerjakannya."25

Toleransi menurut Buaya Hamka toleransi ialah sesuatu yang memaklumi atau membolehkan atas haknya untuk meyakini agama kepercayaan masingmasing. Kutipan cerita yang menggambarkan pendidikan karakter toleransi adalah sebagai berikut: Dari sanalah timbul undang-undang memberi kemerdekaan orang yang mengerjakan dan meyakini agama yang dipeluknya. Bukan saja seseorang tidak boleh dipaksa mengerjakan pekerjaan yang buruk menurut timbangannya, tetapi mesti pulalah di beri kebebasan mengerjakan pekerjaan yang diperintahkan akalnya sendiri.

Menghargai prestasi menurut Buya Hamka menghargai prestasi seseorang ialah perilaku yang baik dan dianjurkan oleh Islam, untuk bisa saling menghormati kepercayaan orang lain.

${ }^{25}$ Ibid, h. 129 
Pandangan Buya Hamka menghargai prestasi ialahyangditunjukan dengan cara memberikan kesempatan pada seseorang untuk menampilkan ide, bakat dan kreasi yang dimilikinya, serta memberikan pujian apabila tugas yang dilaksanakan memberikan hasil yang baik. Kutipan cerita yang menggambarkan tentang nilai pendidikan karakter menghargai prestasi yaitu "Bertambah pandai, kita menjaga perkara ini bertamabah tertariklah hati orang bergaul dengan kita. "Lakukanlah apa yang akan menyenagkan hati orang." 26

Cinta Tanah Air menurut Buya Hamka cinta tanah air ialah seseorang yang berani untuk membela negaranya tempat kelahirannya, tanpa gentar menghadapi sesuatu yang mengancam negaranya dan lebih mementingkan negaranya daripada dirinya sendiri. Kutipan cerita di bawah yang menggambarkan pendidikan karakter cinta tanah air adalah sebagai berikut: Dan karena cinta tanah air itulah orang berani memberikan segala pengorbanan. Karena cintanya kepada tanah air, orang sudi hidup sengsara, sudi dibuang, dibunuh, diazab, dan disiksa. Karena cinta tanah air orang sudi bahkan

${ }^{26}$ Ibid, h. 185 memandang murah harga maut. Tanah air harganya lebih mahal, sebab itu mereka sudi menebusnya dengan jiwanya sendiri. Nilai nyawa menjadi murah buat menebus tanah air; dan mati adalah bukti cinta yang sejati. ${ }^{27}$

Disiplin menurut Buya Hamka pada dasarnya disiplin ialah muncul dari kebiasaan hidup dan kehidupan belajar mengajar yang teratur serta mencintai dan menghargai pekerjaanya. Disiplin adalah sikap mentaati peraturan dan ketentuan yang telah ditetapkan tanpa pamrih. Kutipan cerita yang menggambarkan tentang nilai pendidikan karakter disiplin yaitu "Amat jarang orang yang memikirkan kepentingan mengatur atau merencanakan pekerjaan yang telah diadapi, sehingga kacau-balau pekerjaan setiap hari." 28

Berani Menurut Buya Hamka keberanian adalah harus memiliki hati untuk menghadapi ketakutan, bahaya atau sakit yang diperlukan dalam membela kebenaran. Kutipan cerita yang menggambarkan tentang nilai pendidikan karakter disiplin yaitu "Maka yang patut diberi gelar berani, ialah yang

\footnotetext{
${ }^{27}$ Ibid, h. 310.

${ }^{28}$ Irfan Hamka, Ayah...., h. 12
} 
ISSN 1979-9950 (print) || ISSN 2598-0033 (online), http://jurnal.umsu.ac.id/index.php/intiqad

DOI: $10.30596 /$ intiqad.v11i2.2658

Vol. 11, No. 2 (Desember 2019)

tiada merasa gentar menghadapi bahaya karena menghindarkan bahaya yang lebih besar." "Banyak ahli filsafat dan ahli tasawuf sengaja menempuh bahaya yang ngeri, untuk membiasakan keberanian". 29

Peduli Sosial menurut Buya Hamka peduli sosial ialah sikap yang timbul dari dalam hati untuk memberikan bantuan dengan ikhlas kepada orang lain. Kutipan cerita yang menggambarkan tentang nilai pendidikan karakter peduli sosial adalah sebagai berikut: Maka hubungan di antara tiap-tiap diri dengan masyarakat itu, adalah mempunyai undang undang yang harus timbang terima. Seseorang membayar kepada masyarakat pun membalas pula kepada orang itu. Orang wajib berkorban untuk kepentingan masyarakat dan masyarakat wajib melindungi orang itu. ${ }^{30}$

Rasa Ingin Tahu menurut Buya Hamka Keingintahuan ialah sesuatu menyebabkan seseorang mendekatimengamati, ataupun mempelajari suatu benda ataupun suatu hal lainya. Kutipan cerita yang

${ }^{29}$ Sutoyo, Tasawuf Hamka...., h. 179

30 D. Koesoema, Pendidikan Karakter, (Jakarta: Grasindo, 2007), h. 207. menggambarkan tentang nilai pendidikan karakter rasa ingin tahu yaitu "Umat Islam disuruh mencari Allah dengan akalnya, dan akalnya disuruh menyelidiki alam. Bertambah besar dan subur akalnya, bertambah dekat dia kepada Tuhan."31 "bagaimana terjadinya dan siapa yang menjadikannya? Atau dari mana datangnya hidup itu? Terjadi sendirinya kah atau menjadikan dirinya sendirikah?".32

Cinta Damai menurut Buaya Hamka cinta damai ialah orang-orang yang memiliki keperibadian yang baik pada perangainya, selalu mengutamakan ketentraman dan kemasalahatan masyrakat. Kutipan cerita yang menggambarkan tentang nilai pendidikan karakter rasa ingin tahu yaitu "Carilah orang yang berpikir merdeka dan berbudi utama, yang tentu engkau ketahui kebaikan perangainya dan kesetiannya, serta berani pula menyatakan buah pikirannya pada perkara yang perlu."33

\footnotetext{
${ }^{31}$ Irfan Hamka, Ayah...., h. 12

${ }^{32}$ Sutoyo, Tasawuf Hamka...., h. 83

${ }^{33}$ Ibid, h. 70
} 
INTIQAD: JURNAL AGAMA DAN PENDIDIKAN ISLAM

ISSN 1979-9950 (print) || ISSN 2598-0033 (online), http://jurnal.umsu.ac.id/index.php/intiqad

DOI: $10.30596 /$ intiqad.v11i2.2658

Vol. 11, No. 2 (Desember 2019)

4. Tasawuf

Transformatif

\section{Kontemporer}

Tasawuf Transformatif adalah tasawuf kontekstual, dalam arti, ajaranajaran fundamental tasawuf (agama) berupaya dipahami kembali (reinterpretasi), diberikan landasan filosofis (rasionalisasi), dan didialogkan secara dialektis sesuai dengan konteks problematika umat dalam menghadapi dinamika sosial, ekonomi, budaya maupun politik (relevansi dan reaktualisasi). Sedangkan karakter yang dimiliki Tasawuf transformatif adalah sebagai berikut:

Pertama, memiliki visi keilahian. Dalam dimensi ini, manusia mengawali dengan usaha memahami dan mengenal Tuhan dengan sebaik-baiknya. Penghayatan kepada makna tauhid untuk lebih dekat dan ma'rifat kepada Tuhan ditempuh agar kita benar-benar memahami apa yang Tuhan inginkan dengan segala penciptaan yang berlangsung secara terus menerus ini. Dengan demikian kita akan menyadari betapa semua yang dihadirkan lewat berbagai macam kejadian di alam ini, ternyata Tuhan ada di balik semua kejadian dan secara intens berdialog dengan kita.
Kedua, memadukan antara akal dan wahyu. Tasawuf sering dianggap sebagai jalan untuk mencari kebenaran yang tidak bisa dijelaskan menurut kaidah rasional. Tasawuf transformatif percaya bahwa rasionalitas dan intelektualitas yang berakar pada tradisi masyarakat modern, bukanlah sesuatu yang harus dihilangkan sama sekali dalam menggapai kebenaran dan kebahagiaan hakiki, justru rasionalitas (akal) dan agama (wahyu) adalah dua sisi yang saling menguatkan.

Ketiga, dunia dalam eskatologi Islam. Banyak manusia cenderung memandang dunia dan akhirat secara dikotomis. Bagi mereka, jalan yang ditempuh untuk mendapatkan kebahagiaan akhirat adalah dengan menjauhkan diri dari kehidupan dunia. Tasawuf transformatif meyakini, bahwa kehidupan akhirat (hasil) adalah sebuah proyeksi atas amaliyah seseorang di dunia. Cara kita hidup di dunia akan menentukan kedudukan kita di akhirat. Di sisi lain, kehidupan dunia adalah bagian dari fitrah eksistensi manusia.

Keempat, akhlaqul karimah. Dengan suluk tasawufnya, para salik akan ditransformasi secara gradatif menuju kesempurnaan akhlak. Akhlak yang mulia akan senantiasa menghiasi 
ISSN 1979-9950 (print) || ISSN 2598-0033 (online), http://jurnal.umsu.ac.id/index.php/intiqad DOI: $10.30596 /$ intiqad.v11i2.2658

Vol. 11, No. 2 (Desember 2019)

perilaku para sufi baik terhadap Tuhan, alam dan sesamamaya.

Kelima, amal shalih yang berdimensi sosial. Amal shalih didefinisikan sebagai setiap usaha dalam memperbaiki kondisi lingkungan hidup kita. Baik-buruk dan rusak-lestarinya kehidupan ini semua bergantung pada apa yang manusia lakukan. Dalam konteks ini, bisa dikatakan tidak ada tasawuf tanpa amal shalih yang berdimensi sosial, seperti: menyantuni fakir miskin, pemberdayaan ekonomi masyarakat bawah, peduli pada kelestarian alam, dan berperan aktifkreatif dalam penyelesaian berbagai macam problematika masyarakat dan lingkungannya.

\section{Simpulan}

Perspektif pemikiran pendidikan karakter Buya Hamka adalah bahwa fitrah setiap manusia pada dasarnya menuntun untuk senantiasa berbuat kebajikan dan tunduk mengabdi kepada Khaliqnya. Jika ada manusia yang tidak berbuat kebajikan, maka sesungguhnya ia telah menyimpang dari fitrahnya tersebut. Hamka juga berpendapat bahwa pada diri manusia terdapat tiga unsur utama yang menopang tugasnya sebagai khalifah fi al-ardh maupun 'abd Allah. Ketiga unsur tersebut antara lain akal, hati, dan pancaindra.

Dalam membentuk kepribadian anak, tidak terlepas dari pendidikan orang tuanya. Orang tua seharusnya membentuk anaknya mengikuti masa anaknya.Oleh karena itu, kepandaian dan pendidikan orang tua dalam mendidik anaknya akan sangat membantu pekerjaan guru.Pembentukan karakter yang sederhana dapat diperolah dari akal orang yang bijaksana, maka hubungannya dengan pendidikan sangat berpengaruh. Maksud dari pendidikan ialah membentuk anak supaya menjadi anggota masyarakat yang berguna dalam pergaulan hidup. Halini yang dimaksudkan Hamka dari pendidikan karakter ialahmembiasakan berkata terus terang (jujur). Berani karena benar, sabar atas rintangan dan bantahan, tahan kena kritik, dan kuat serta teguh.

\section{Daftar Pustaka}

Abdul Rouf, \& Mohd Yakub Zulkifli Mohd Yusoff. (2013). Tafsir al- 
INTIQAD: JURNAL AGAMA DAN PENDIDIKAN ISLAM

ISSN 1979-9950 (print) || ISSN 2598-0033 (online), http://jurnal.umsu.ac.id/index.php/intiqad

DOI: $10.30596 /$ intiqad.v11i2.2658

Vol. 11, No. 2 (Desember 2019)

Azhar dan tasawuf menurut

Hamka. Jurnal Usuluddin.

Ainiah, N. (2013). Pembentukan

Karakter Melalui Pendidikan Agama Islam. Jurnal Al-Ulum.

Alwisol. (2006). Psikologi Kepribadian. Malang: UMM.

Abdullah, Amin. 1996. Studi Agama: Normativitas atau Historisitas. Yogyakarta: Pustaka Pelajar.

Bronfenbrenner, U., Morris, P. A. (1998). The Ecology of Developmental Processes. In W.

Damon (SeriesEd.) \& R. M. Lerner (Vol.

Ed.), Handbook of Child Psychology: Vol. 1:

TheoreticalModels of Human

Development. New York: Wiley

Damami. 1992. Tasawuf Positif,

Pandangan Hidup Muslim

(Jakarta: Bulan Bintang,)

Hamka, Irfan. 2014. Ayah (Kisah Buya

Hamka: Masa Muda, Dewasa,

Menjadi Ulama,

Sastrawan, Politisi, Kepala Rumah Tangga sampai ajal menjemputnya. Jakarta:

Republika Penerbit.
Hamka. 1957. Ghirah dan Tantangan Hidup Umat Islam. Jakarta: Bulan Bintang.

1982. Ayahku. Jakarta: Ummindo. -.2001. Lembaga Hidup. Jakarta: Pustaka Panjimas. 2012. Pelajaran Agama Islam. Jakarta: Bulan Bintang. 2014. Tafsir Al Azhar Jilid 1-9. Jakarta: Gema Insani.

--------. 2014. Tenggelamnya Kapal van der Wijck. Jakarta: Balai Pustaka. 2015. Falsafah Hidup. Jakarta: Republika Penerbit. 2015. Lembaga Budi. Jakarta: Republika Penerbit.

Hamka, Irfan. 2016. Ayah, (Jakarta: Republik Penertbit), h. 290

Koesoema, D. (2007). Pendidikan Karakter. Jakarta : Grasindo.

Megawangi. (2008). Character Building (Tinjuan Berbagai Aspek). Yogyakarta : Tiara Wacana

Madjid, Nurcholis. 1997. Tradisi Islam: Peran dan Fungsinya dalam Pembangunan di Indonesia. Jakarta: Paramadina.

Siradj, Said Aqil. 1994. Silat Allâh bi alKawn: fì al-Tasawwuf al-Falsafì. Makkah: Jâmi‘ah Umm al-Qurâ. 
INTIQAD: JURNAL AGAMA DAN PENDIDIKAN ISLAM

ISSN 1979-9950 (print) || ISSN 2598-0033 (online), http://jurnal.umsu.ac.id/index.php/intiqad DOI: 10.30596/intiqad.v11i2.2658

Vol. 11, No. 2 (Desember 2019)

Sutoyo. (2015). 'Tasawuf Hamka dan

Sufistik Hamka”. Esoterik:

Rekonstruksi Spiritual Manusia

Jurnal Akhlak dan Tasawuf.

Modern." Islamica: Jurnal Studi

Keislaman.

Ulfah, N. M., \& Istiyani, D. (2016).

"Etika Dalam Kehidupan

Modern : $\quad$ Studi Pemikiran 